\title{
Negotiated Precarity in the Global South: A Case Study of Migration and Domestic Work in South Africa
}

\author{
ZAHEERA JINNAH \\ University of Victoria, Canada ${ }^{1}$
}

\begin{abstract}
This article explores precarity as a conceptual framework to understand the intersection of migration and low-waged work in the global south. Using a case study of cross-border migrant domestic workers in South Africa, I discuss current debates on framing and understanding precarity, especially in the global south, and test its use as a conceptual framework to understand the everyday lived experiences and strategies of a group that face multiple forms of exclusion and vulnerability. I argue that a form of negotiated precarity, defined as transactions which provide opportunities for survival but also render people vulnerable, can be a useful way to make sense of questions around (il)legality and (in)formality in the context of poorly protected work, insecure citizenship and social exclusion. Precarity as a negotiated strategy shows the ways in which people interact with systems and institutions and foregrounds their agency. But it also illustrates that the negative outcomes inherent in more traditional notions of precarity, expressed in physical and economic vulnerability, and discrimination in employment relations, mostly hurt the poor. This suggests the importance of an intersectional approach to understanding precarity in labour migration studies.
\end{abstract}

KEYWORDS: domestic work; gender; migrant labour; precarity; race; South Africa

\section{Introduction}

Precarity is widely used and studied in the applied and academic literature, and across disciplines (Millar, 2017; Neilsen \& Rossiter, 2008; Standing, 2014). At its core it refers to a condition of chronic insecurity and weak

\footnotetext{
${ }^{1}$ The author is also affiliated with the African Centre for Migration \& Society, University of the Witwatersrand, Johannesburg, South Africa.
} 
citizenship rights (Standing, 2011, 2014). In the labour literature, precarity refers to a class of workers, known as the precariat, who are in insecure and unstable jobs. Sociologists trace precarity to a consequence of neo-liberal systems of capital accumulation which erode labour protections such as job security, benefits and protection on the one hand, and to the parallel decline of welfare states which offer socials security protection on the other. The precariat therefore are workers whose everyday existence is characterised by a sense of instability and vulnerability. For migrant workers, an insecure citizenship status compounds this vulnerability by narrowing their choices in the labour market and making them more at risk of exploitation.

Despite this rich body of work, there have been fierce critiques of precarity structured along two lines: first, questioning its relevance as a new and political concept; and second, testing its applicability in the global south (Barchiesi 2011; Pang, 2018; Paret, 2016; Rogan, Roever, Chen \& Carré, 2017; Scully, 2016). It is within this framework that I attempt to further explore what precarity means in the global south under conditions of international migration and low waged work, and conversely how using precarity as a conceptual framework can serve as a bridge between the relatively unexplored connections between international migration and labour studies in southern Africa.

In this broader context, I use a case study of cross-border migrant domestic workers in South Africa to explore further what precarity in the global south looks like under conditions of migration and low waged work. How do we describe and theorise it? And how does it resonate with the lived experiences, both the "positive" and the "negative" of this group?

The outline of this article is as follows The next section provides some background on domestic work and migration in South Africa, and the broader global scholarship in this field. It serves as a context and rationale for the selection of this sector as a case study in the global south. I then summarise the key developments in precarity as a concept, showing how a deeper and broader understanding that uses evidence from multiple locations is needed. The bulk of the article attempts to do this by developing a case for "negotiated precarity." Using empirical material on domestic work in South Africa I show how negotiated precarity can serve as a conceptual framing of the insecurity and strategies of a group of vulnerable workers. I end with some thoughts on the limitations of and opportunities for a deeper study of the concept with a social justice approach

\section{Context: Domestic Work and Migration in South Africa}

In South Africa, there are 1.2 million domestic workers representing $11 \%$ of the labour force (Statistics South Africa, 2013). Three quarters of all domestic workers are women with low levels of education (only 12\% have completed high school); almost all are black. The sector is a considerable 
source of employment for black women in South Africa (Statistics South Africa, 2012b). Domestic work is poorly paid with $71 \%$ of workers reporting a monthly income of less than CAD \$320 a month. ${ }^{2}$ About half of all domestic workers, regardless of migration status, have a household income less than the prescribed minimum wage level for the sector (Statistics South Africa, 2012a). Access to working benefits is low among all domestic workers with the exception of a regular wage increase. Only one percent of all workers regardless of country of birth have access to medical schemes or paid maternity leave. Only 19\% have a written contract (Statistics South Africa, 2012a). Domestic work is therefore a sector in which enforcement is problematic leading workers to experience a number of vulnerable conditions, including limited labour protection, low wages and little recourse to protect against exploitation

International migrants are disproportionately represented in South Africa's domestic work sector. Despite accounting for just four percent of the overall labour force, migrant workers constitute $13 \%$ of all domestic workers (Statistics South Africa, 2012a). The majority of migrant domestic workers come from the Southern Africa Development Community (SADC) region, ${ }^{3}$ and about $20 \%$ of all SADC migrants work in the sector. Disaggregating further, workers from Zimbabwe account for over half (52\%) of the private household workers from the SADC region, followed by more than a fifth (22\%) from Mozambique, and 10\% each from Lesotho and Malawi (Statistics South Africa, 2013).

\section{Methods}

This article is based on four months of ethnographic fieldwork in three South Africa cities: the largest economic and migration hub, Johannesburg; the capital, Pretoria; and eMalahleni, a smaller mining city on the MozambicanSouth African corridor. This produced 59 semi-structured interviews, conducted in 2014 and 2015, with the following groups of participants:

- Three directors or managers from three different employment agencies which specialise in placing domestic workers with private household employers;

- 25 employers of domestic workers. Employers were all female, and selected from two sources: 12 were recruited using random sampling from a data base of 1500 employers kept by a recruiting agency, and 13 were

\footnotetext{
${ }^{2}$ Statistics South Africa (2012b)The Census 2011 included a question (Paragraph16) asking for the income category that best described the gross income (including all sources of income) of each individual before deductions. The responses to this question are not necessarily equivalent to income earned as a private household worker, as individuals might also have other sources of income. The responses should, however, provide some approximation of earned income.

${ }^{3}$ The Southern African Development Community (SADC) is a regional economic bloc of 15 member states.
} 
selected using convenience sampling from social networks;

- 34 domestic workers, including 10 South Africans, eight from Lesotho and 16 from Zimbabwe. Workers were selected from multiple sources: 12 from random sampling from the data base of an employment agency, 12 through snowballing, and 10 from community level sampling in neighbourhoods where migrants live, to ensure representation from this group.

In addition, a research assistant undertook participant observation, focus group discussions and informal discussion with a group of eight migrant domestic workers on their journey home to Leostho from Johannesburg on public minibus, as well as on their return journey to Johannesburg two days later. This includes observations of crossing the international border between the two countries.

All fieldwork was done by the author and a research assistant, who was an MA student under the supervision of the author. The research was carried out under the approval of an ethics certificate from the author's home institution.

\section{Care Work and Vulnerability}

The global literature on domestic work provides an opportunity to examine the points at which migration and labour studies overlap. Given the overwhelming and complex forms of vulnerability and exclusions in this sector, which I summarise below, the domestic work sector provides a helpful case study to examine the construction of precarity.

Care work is a core sector of employment for female migrant workers. Current estimates (with limitation on counting a difficult to access population group in mind) suggest that there are 67.1 million domestic workers in the world, of which 11.5 million are international migrants. Amongst the latter, almost $80 \%$ are migrants from the global south working in the domestic work sector in high income countries, and $73.4 \%$ are women (International Labour Organization, 2015).

Feminist scholars initially understood care work as unpaid housework and child-care by middle class women. Since the 1970s there has been a healthy interrogation of the globalised and transnational aspects of reproductive labour (Arat-Koc, 1989; Crenshaw, 1991; Parreñas, 2000; and Sassen, 2000). This scholarship explores the multiple and interconnected ways in which social relations and identities converge, especially among women of colour working in the global north (Crenshaw, 1991; Duffy, 2011 Glenn, 1992). Later studies include a focus on migrant women (Bakan \& Stasiulis, 1995, 1997; Parreñas, 2000; Stasiulis \& Bakan, 2005), arguing that migration is used to meet household demands created by labour market needs.

This literature theorises a globalised care chain of racialised and gendered exploitation from the global south to the north (Anderson, 2010; Yeates, 2009) where low wages, long hours and minimum access to rights are a reality (Budlender, 2010; Parreñas, 2000). In migration studies, the 
feminisation of migration explores race, mothering, transnational families, gender roles and norms, and violence in the context of citizenship rights (see e.g., Andall, 2017; Piper, 2005).

Despite this research, there is limited scholarship on migrant domestic work circulating in the global south, under conditions of irregular migration. This is important because as Kofman and Raguram (2012, p. 410) point out, "levels of growth, migratory systems, gender regimes, and welfare arrangements all vary across countries." How then do conditions in the sector differ from the rest of the world, if at all, if we take a feminist, political economy approach? How do we best theorise these conditions? How do we better understand the heterogeneity of global care chains, the perspectives of employers and workers, and the dynamics and patterns in one part of the global south? And, can we use evidence from this case study to raise broader questions on, and (re) construct precarity as a concept?

Cross border migrant domestic work in South Africa presents interesting dimensions to the study of global care chains. Building on a historical tradition of internal migration work in the sector, and of gendered and racialised employment patterns, domestic work in its current form straddles formality and informality. More recently, an international migration regime that is strewn with informality, corruption, and xenophobia adds further complexity to this context (Jinnah, 2017; Landau, 2010, 2018).

Ally (2009), Bystrom and Nuttall (2013), and Gaitskell, Kimble, Maconachie and Unterhalter (1983) show the gendered and racialised history of the sector. Until the 1990s, domestic work in South Africa was not considered a legal category of employment under labour legislation developed in the colonial and apartheid periods. Workers held no rights under labour law, and the employment relationship was governed by few standards. In policy and practice, domestic workers were seen as little more than (black) servants to (white) households, who held few human rights. They faced dehumanising practices of eating using separate utensils, working long hours, having limited contact with their families, and facing severe mobility restrictions in urban areas, unless they held a permit allowing them to work (Ally, 2009; Budlender, 2010; Peberdy \& Dinat, 2005). This conditioned an employment relationship marked by an imbalance of racialised power.

After 1994, South Africa developed and implemented a series of policy reforms aimed at recognising, regulating and better protecting workers in the sector. These were a result of strong advocacy from within the trade union sector and with support from civil society and the governing party. All of these by extension include migrant domestic workers, due to the referencing of "residents" rather than "citizens" in the Constitution. Key reforms have consisted of the introduction of regulations such as The Basic Conditions of Employment Act of 1997, which for the first time stipulated hours of work, leave and rest periods, mandatory obligations on the part of the employer in terms of providing notice and job tasks, and in 2002, minimum wages for the sector through a Sectoral Determination for Domestic Workers. In 2013, 
South Africa also ratified the first international convention on domestic work, the International Labour Organization (ILO) Convention on Domestic Workers, 2011 (No. 189). Consequently, in policy, domestic workers, both local and foreign-born in South Africa, are legally recognised as employees and can rely on a wide spectrum of national policies and international standards to protect their rights.

In practice over the last two decades, however, outcomes have only slightly improved. The literature on domestic work shows that non-compliance is common in the sector as household work is difficult to regulate, given challenges in accessing the worksite and employees. In South Africa, the response to low compliance has been to tighten the regulatory space, introducing new laws on minimum wages, for example, and to increase awareness campaigns for workers to demand their rights. However, there have been few successful attempts to increase the enforcement mechanisms by, for example, beefing up inspectorates or instituting punitive action such as issuing fines to non-compliant employers. There is also an assumption that compliance will increase with awareness. Consequently, little attention has been paid to how workers and employers understand and rationalise the law and the working relationship.

Since the 1990s, migration patterns have also shifted. Economic and migration polices during apartheid separated the productive and reproductive costs of labour through a temporary and circular labour migration regime servicing the core sectors of the economy (Buroway, 1976; Moodie and Ndatshe 1994; Wolpe, 1972). This enabled access to a cheap supply of labour and the maintenance of a political project. In the post-apartheid period, this system of influx control has given way to what I describe in this article as a regime of formal-informal migration and labour control which criminalises low skilled migrants and puts them at risk of exploitative labour practices (see also Jinnah, 2017). On the migration side, a restrictive immigration policy framework effectively makes it impossible for low skilled workers to obtain a work permit, pushing many into undocumented status and poor paying jobs (Polzer- and Segatti 2012). Migrant workers from the southern African sub-region are currently disproportionately represented in low skilled sectors, especially domestic work in the South African labour market.

Finally, in parallel with the scholarship in migration studies, there is ongoing work in labour (Bolt, 2015; Kiwanuka, Jinnah \& Hartmann-Pickerill, 2015), which shows that low skilled workers and black women bear the brunt of neoliberal capitalist policies and practices which leave them economically poor and socially vulnerable. Some of these analyses use the conceptual framing of precarity, demonstrating the contribution and challenges of evidence from the global south (Bolt, 2015; Griffin, 2011; Scully, 2012) 


\section{Deconstructing Precarity}

Precarity has been traditionally understood as a bounded historical condition of labour transformation under conditions of globalisation coupled with a declining welfare state. Extensively used in Europe as a force for organising a study of everyday experiences and a tool to question the state's role in politics and society, it has extended to sociological constructions of labour studies, migration, political science, and anthropology (Neilson \& Rossiter, 2008; Standing, 2011).

More recent work focuses on understanding and critiquing precarity beyond this initial scope, by exploring its plurality and diversity to question its rigour and basis as a theoretical construct. This critique has largely been constructed along two lines. First is the validity of the concept given a very limited inclusion of evidence beyond the global north. Munck questions if the term is, "novel or even relevant, for the millions of workers and urban poor in the global South for whom precariousness has always been a seemingly natural condition?" (2013, p. 747). He likens precarity to older concepts of marginality, social exclusion and informality. Scully's $(2012,2016)$ work on labour precarity in South Africa has taken a more historical and structural approach, embedding the drivers of precarity in longer trajectories of exclusion that characterise the developing state. He argues that some of the inherent characteristics of the concept (such as conditions of poorly protected labour and minimal state assistance) are part of a longer history and reality for citizens of low and middle income countries. As he says, "treating precarity around the world as a single phenomenon, produced by globalisation, the work of Standing and others obscures the different and much longer history of precarious work in the Global South" (Scully, 2016, p. 162).

Second, the concept of precarity itself as something "new" has been questioned. Munck and others such as Banki (2013) have shown that other conceptual tools such as informality and exclusion have been used to define and discuss the same characteristics that we associate with precarity. For instance, the informal economy marks "not only the reorganization of labour but also the accompanying ways in which the uncertainty of securing a livelihood bleeds into other aspects of life" (Parry \& Hann, 2018, p. 334).

Moving beyond labour, I nonetheless argue that precarity can serve as a useful frame to analyse the everyday struggles of the marginalised and the transactional nature of survival As Schierup, Munck, Likic-Brboric and Neergaard (2015) state, by exploring "varieties of precarity" we could arrive at new ways to understand and address older issues of vulnerability and exclusion, especially in the context of the politics, economies and societies of the global south. Here they emphasise migration and labour transformation as characteristic of a "duality of flexibility." However Jørgenssen and Schierup (2016), like Standing (2011), warn of an insurgency by migrant workers in response, when this flexibility becomes untenable. By situating precarity as 
representing "both a condition and a possible rallying point for resistance" (Waite, 2009, p. 412), there is a risk of implying some sense of danger that threatens the status quo associated with being poor and vulnerable. Writing on South Africa, they state (Jørgenssen \& Schierup, 2016, p. 1057):

A composite precarious labour pool is overwhelmingly black, to a considerable degree migrant, and increasingly female. The spaces it occupies become, in turn, sites for active reproduction of ... where the poor employ inventive livelihood strategies which are beyond the reach of formal regulatory frameworks.

So how do we understand precarity and what use, if any, does it have for studies of migration and labour in the global south? I identify three ways in which it can add value: first, a plurality of evidence especially from the global south is needed to (re)construct what precarity means. This study shows how precarity can be understood as multiple forms of exclusion and vulnerability at the intersection of migration and labour and rooted in racialised and gendered experiences. Second, it is useful to understand how legality and informality cross in complex ways. The concept of precarity challenges what we understand as legal by using language that begins with lived realities rather than norms. Third, I retain the sense of precarity as a concept to explain the multiple forms of vulnerability that people experience as labour migrants; its conceptualisation needs to be reframed and broadened, deconstructing aspects of danger and emphasising the various strategies for survival that people develop. Throughout this, a process of negotiating safety, certainty and survival is inherent.

\section{Precarity in the Global South: Diverse and Different?}

\section{Legal Exclusion}

In much of the literature on precarity, weak citizenship status is identified as a contributing factor to conditions of precarity. In global care chains migrant domestic workers face a legal regime in which they are temporary workers who move away from their families and enjoy limited rights as sojourners. Using Goldring, and Landolt's (2011, p. 328) articulation, precarious migratory status is defined as "the multiple and variable forms of 'less than full status', and is defined by the absence of key rights or entitlements usually associated with the full or nearly full status of citizenship and permanent residence." In the case of migrant domestic workers in South Africa, legal insecurity goes further: it stems from restrictive immigration policies (the institutionally rooted precarity) coupled with corrupt institutions and social marginality. This is indicative of south-south migration regimes in general and points to a different way in which weak citizenship status can be defined. The precarious in the global south do not only have weak citizenship status, but their everyday existence is an attempt to circumvent detection and survive 
as undocumented migrants, often at risk to themselves. They do so through a process of navigating and negotiating rights and safety.

For cross border migrants, the lack of a consistent and comprehensive labour migration policy that facilitates the entry and work of lower skilled regional migrants results in limited access to rights. From 1994 to 2009, low skilled migrant workers could not obtain a work or work seekers permit in South Africa. In 2009, the first of three temporary measures known as special dispensations came into law. These mechanisms were introduced following the political crisis in Zimbabwe after the 2008 election in that country and subsequent legal advocacy from human rights groups campaigning for the resulting hundreds of thousands of undocumented Zimbabweans living in South Africa at the time. There were three special dispensations between 2009-2018, two for Zimbabweans and one for nationals from the landlocked Kingdom of Lesotho. All allowed for temporary regulation of undocumented migrants provided that certain obligations were met. Several studies point to the low efficacy of these dispensations. Some of the sharper criticisms included the practical difficulties of accessing an online system, corruption in the ministry, and very narrow eligibility requirements (Amit \& Kriger, 2014; Hopstock \& de Jaager, 2011; Nshimbi \& Firiamonti, 2014). Consequently, low skilled worker seekers used a range of informal measures to enter or work in South Africa. These include using the relatively generous asylum seeker route which allowed for freedom of movement, access to work or study, but with very limited time frames; entering as a visitor under the sub region's visa free entry, which did not authorise work; or entering irregularly as a "border jumper." Some of the respondents explained their status and strategies as follows:

The first thing is that we are never steady, the police are always after us because we don't have IDs. (Interview with N)

You only survive when your passport is valid. (Focus group discussion, Oct. 24, 2015)

When you go and apply for a South African work permit they don't give you, they only give students study permits. I went and asked for it and they told me that they only give [it to] people working for the government. (Interview with R)

In the qualitative sample, $42 \%$ of women were undocumented migrants, $31 \%$ had entered under the regional tourist visa and did not have a work permit, and $27 \%$ had a temporary asylum permit, which needed to be renewed every month or 90 days. Most of the participants had valid passports but none had a work permit.

Ethnographic observations at the Lesotho border show some tactics of survival. When getting off public transport at the Lesotho border, young men who loiter about, ask if your passport is "okay." By this they want to know if your visitor visa is still valid, or if you have overstayed it or have no passport 
at all. For a fee they can help you cross the border without valid documents (Field notes, Oct. 2015):

They check the passport, they see that we have broken the law, we give them a few sweets to pay for those exceeded days. Otherwise if you don't pay they destroy that passport. (Interview with B)

These days it's R200 (CAD \$20) I think. They charge whatever they want. If you don't want your passport to be destroyed you are going to pay that amount. (Interview with B)

Most of the Zimbabwean domestic workers said they use an informal system known as Malaesha (oMalayitsha). These are long distance trucks and other vehicles that come from Zimbabwe to Johannesburg who smuggle in women. Two of the respondents stated that they performed sexual favours to the drivers as a payment for smuggling. Others cross the Limpopo River that divides the two countries:

I was a border jumper, I don't have a passport. [I came with] my aunt, she is blind but now she passed away. We came to Beitbridge [border]. When we were in Beitbridge, we find some other people; they said "we gonna help you." They went with us inside the Limpopo [river, and helped us to] cross the river... On the other side we were in South Africa. (Interview with M)

\section{Informal Work}

A second form of negotiated precarity is in the informal employment patterns and relations in a formal (regulated) sector. This is not due to erosion of labour standards as in the north, but rather to a weak institutional structure that fails to support compliance to norms and to poor attitudes amongst employers that hinder compliance.

Working conditions amongst the respondents were poor with long hours stretching to 12 hours a day, no written contracts, no paid leave, minimal time off, unclear job descriptions, and no job security being the most cited amongst all the domestic workers. This highlights the strong sense of informality and lack of compliance to the law in the sector. The quotations below highlight some of the experiences of workers regarding conditions. They speak to the ingrained racialised and subjective perceptions of rights and social orders. One respondent, who is a migrant domestic worker from Zimbabwe says:

I start working at 5am and leave when the lady comes home. I can't leave unless they are home or unless if they have a day off then I can leave early. (Interview with K) 
Another respondent talks about the lack of legal protection she faces as an undocumented migrant worker:

I don't have a contract, I don't even have a working permit. (Interviewer: Does your employer know that you don't have a work permit?) She knows, she knows. (Interview with $\mathrm{N}$ )

When asked if she has a fixed schedule of work, this woman replied:

I worked all day, in the morning, until at night when I have to wash the dishes, I cannot go to bed while the dishes are dirty so I have to wait for them to finish eating. (Interview with T)

A concern amongst respondents were low wages, with all women stating that a salary of between R1000 and R2000 a month (CAD \$100-200) was not sufficient to live on. As one respondent said:

It's little. I can't do anything with that much money. Because that amount that my employer pays me, she can buy one pair of shoes with that money. She buys a pair of shoes with that money but she expects me to support my family with it, transport to work, everything. (Interview with B)

The informality of work suggests more than a lack of awareness among workers and employers on rights and obligations. In general, the employers and employment agencies knew and understood the legal framework governing the sector. Employers were aware of regulations pertaining to wages, contracts, working hours, and benefits. However, they reported mixed and vague responses in terms of compliance. Many of the agencies noted that at the initial stage of the recruitment process when they worked with employers to identify their needs and find a suitable worker, employers said that they paid less than minimum wage and did not recognise the need to ensure that employees have a written contract. Employers themselves admitted that they were not fully compliant, especially when it came to contracts, and hours of work. At other times, workers reported that employers agreed to a higher wage but later paid less than what was agreed.

The reason for the differences in compliance was based on a flexible understanding of their obligations as employers and their perceptions of what constituted "fairness." For instance, a number of employers highlighted that in lieu of paying minimum wages, employees got access to meals and accommodation, or that employers would pay for private doctor consultations for employees and their families. In other instances, employers stated they would pay what they could afford, and that low wages were better for the employee than unemployment.

Although domestic work is covered by legislation, in the lived experiences of domestic workers and employers in this study it is regarded as informal labour, a type of private practice occurring between the employer and worker, governed by the needs and values of employers. Inherent to this is a great 
deal of uncertainty on the core aspects that are meant to be regulated: wage levels, benefits, working hours, etc.

A personal relationship is of course common in many service-related and care-oriented sectors of work, but here I trace the power and dynamics of such a relationship further, to explain the prevailing social relations between employers and employees which are characterised by inequities in gender, class and race that continue to be relevant in a post-democratic period. This imbalance of power skews social relations and allows for the persistence of flexible practices despite clear labour regulations. As one respondent said:

If they don't pay me (my salary on time), I can just keep quiet because I didn't sign any contract with them. What if I lose my job? Who is there to help? (Interview with L)

In general all the employers and agencies who represent employers reported a healthy sense of awareness of their obligations, but reported mixed responses in terms of compliance. Agencies noted that far too many employers in their data bases (in total amongst four agencies 1500 employers were recorded) offered less than minimum wages and did not recognise the need to ensure that employees have a written contract. Employers themselves admitted that they were not fully compliant, especially when it came to contracts and hours of work.

Employers noted in interviews that they had a good relationship with their employees, stating that they considered them to be part of their families, that they shared mealtimes together, and that the relationship was personal. In many instances employers said that they gave their workers clothes, helped with workers' children's school fees, and provided loans to them at times. But their narratives are laced with veiled notions of racism and stereotypes. An employer who is white and helps her friends finds domestic workers, commented as follows on employment relations:

It's only until you start hearing from the maids how your friend actually treats them, it is actually quite horrific. And I placed Aya with Berta, she was a helper. So Berta had a full-time maid, South African, called Maria [who] could cook like a dream and she could look after babies and clean house, but they built up so their house became too big; it was like a seven bedroom house. So Aya would go in there three days a week and help Maria clean. When I say, and Berta was quite well off to pay a decent salary, so Aya asked for R150 (CAD 15) a day, which is actually like sort of the going rate, Berta then said to her, 'fine, but you bring your own lunch, you drink your own water.' How can you say that to someone? (Interview with A)

Another employer said:

Growing up, I had a maid or we had a nanny my entire life. She was with my family for 47 years. The sad thing is I don't know where she is today. Matilda came up from Durban after my Gran passed, and then my mom and her ex- 
husband lost their house and everything and Matilda disappeared with the house and everything else like that. So for 47 years she looked after my family and I don't even know to this day if she's dead or alive. That's sad. Very sad. I don't even know her surname, you know what I mean? (Interview with G)

That's the perception that people have that hire Zimbabweans, that they are replacable in five seconds because there's so many. Or it's also the perception that they'll stay because they can be treated like shit because they'll accept it and that's terrible in itself. (Interview with A)

A respondent who acts as an informal placement agent for domestic workers said:

With regards to pay, the wage is dependent on what area the employer is located in - so if someone in a nice area with a house with many rooms is asking for little pay, then something is wrong - I will run away from people who wish to exploit people like this. People know about the minimum wage, but they don't think about others and are used to getting their way, so they only want to pay little and the domestic workers because they're poor so employers think they're stupid. (Interview with D)

A respondent, who is a manager at an employment agency that recruits domestic workers, spoke about the perceptions of difference between local and migrant workers:

Foreigners and South Africans come with a bit of a different mindset. The foreigner has come far to try and look for employment, she doesn't really have a home in South Africa, she's coming here to work and to earn a living. So she doesn't really have a home so she's a little bit more comfortable to seek live-in employment. And it also benefits them most of the time, because they don't have to pay rent because it comes as part of the package. They don't have a home in South Africa, they've come to South Africa to work. So it's easier for them to go and like I said, it benefits them as well. So they're getting a place to live, a lot of times there's a dinner included and the money you get at the end of the month you're able to save. (Interview with V).

The sentiment that migrant workers have an advantage in the labour market was shared by many employers in the sample. One respondent stated:

They (migrants) want to work. They want to come here and they want to set up a life and they want to work hard. And they don't mind doing domestic chores. You'll get ladies who come here and they've got teaching qualifications, and they come here and they'll happily be a nanny because they see it as their earning an income that they can send home to their kids and they're still working with children, which is what they want to do. And we just find that they're more service oriented, if I can put it that way. They want to, they acknowledge that they're being paid for a service and they're happy to deliver that service. (Interview with S) 
Another recruiter in the sample said that migrants are less likely to negotiate employment conditions compared to locals:

I think also with the foreigners, they are easy to communicate with, you know. They are very open, they are easy to communicate with. They will never say, "no, but why are you doing this like this, why can't you do this like this, why is she paying me this amount of money?' They never complain. (Interview with W)

An employer in the sample discussed these views in more detail:

There's a big difference, culturally and everything, emotionally. The way they are, the personality. You just see it here - and I say this in complete confidence, because I love the people that I work with here - the South Africans, yes apartheid was harsh, by all means, I wasn't part of it, I was too young, I was born in 1976. I grew up, yes, with it, but didn't understand it. The problem I find now is the younger generation are still harbouring that hatred and we never gonna get past that, it's gonna take a long time, more than 100 years I think. Everyone's got to stop living in the past and actually start moving on, you know, stop demanding. Yes our country is... you battle, everyone's battling, but it's - how to say it Zimbabweans are happy to get on with life, no matter what they've got or what they haven't got. They always got a smile on their face. I can give you five Zimbabweans here and compare them to five South Africans and I'll put them in a room and you tell me who are the Zimbabweans and who are the South Africans. You'll tell instantaneously who they are, they're just happy people. (Interview with GL)

Yet workers stay in these employment relations, preferring them over other low waged work such as street trading, or retail assistants, using them as a means to earn a livelihood, or save money. They tolerate the negative experiences as it allows them to migrate, to work and to survive. Some quotations from interviews with domestic workers illustrate this attitude. A migrant worker from Zimbabwe spoke about why she works in this sector:

I took a job as a domestic because I heard the lady gives us clothes, and helps with my passport and even takes me to the doctor. Everyone wants a Zimbabwean lady to work for them because we work hard and we don't complain. (Interview with B)

Another Zimbabwean migrant worker discusses how any employment is better than none:

My family's life it's better now because, they now have food, clothes, blankets to put over unlike before. (Interview with Y)

A respondent from Lesotho was in agreement that migrant work allowed her to escape poverty:

When I was in Lesotho I was so poor! For me to cook pap [thick maize porridge] I would have to go to the neighbours. They would say oh here comes the 
lunchbox carrier do you hear me? I would then have to go to another one, they would get irritated. And when I worked on these contract jobs, I would spend the whole month in debt. (Interview with $\mathrm{N}$ )

For this respondent, who is undocumented, working in a private household provides some protection from being detected by the authorities:

We are safe here. We have work, we have a place to stay. Police don't come to the suburbs asking for our passports. So we act like we don't care when the boss shouts, because inside we are the ones laughing. (Interview with $\mathrm{M}$ )

Finally, many respondents, including this woman from Zimbabwe, spoke about how they are able to save and improve their lives even by holding poorly paid jobs:

Every month I put something away as a saving and I can build my own house at home with it. R100 (CAD \$10) is not much here but in Zimbabwe it buys a lot. (Interview with GM)

These narratives show both how racialised and gendered employment extends and persists in South Africa under conditions of progressive labour legislation, yet how precarity is negotiated by workers themselves, suggesting a form of agency. It is this agency, exercised in the choices workers make to migrate without secure legal status, and to work under conditions of informal labour, that informs the concept of negotiated precarity that I develop here. New dynamics of cross border migration add additional layers of stereotypes that the literature in South Africa on domestic workers has not yet considered. Many of the interviews with employers included reference to stereotypes as "the honest, hardworking or happy foreign worker." Given the likelihood of ongoing regional migration, in the context of insecure citizenship rights and weak institutional capacity to enforce regulations, these dynamics are important factors that will shape this sector in the country and region.

Equally, qualitative research that shows the nuanced dynamics of employment relations from both the employers and workers side, is important. Using this approach it is possible to discern the ways in which workers make sense of their status and they ways in which they respond to it.

\section{Conclusion}

This study thus brings us back to precarity as a conceptual framework. The findings here show multiple forms of vulnerability and exclusion, including low wages, poor compliance, irregular migration status and discriminatory employment practices. In order to understand the everyday realities and responses of migrant domestic workers in South Africa, a form of negotiated 
precarity rooted in the realities of the global south is a conceptual lens that help make sense of how formality and legality intersect and produce informal negotiated conditions. Deconstructing precarity from its focus on a northern context of eroding labour rights and weak state protection, which give rise to a "dangerous class," is a first step in critiquing precarity. By broadening precarity beyond labour to everyday strategies and survival, it is possible to reconstruct the concept and pay attention to how laws and behaviour intersect, and how people use their own agency through these power dynamics. In this example, navigating legality in migration status and negotiating security through informal employment relations are ways in which migrant domestic workers secure livelihoods and take care of their families. The danger of the poor remaining outside of the protection of labour or citizenship rights continues, especially in the global south, but the brunt of this danger, expressed in poverty, exclusion, discrimination and vulnerability, is likely to be faced by workers themselves, rather than presenting any threat to the order or hegemony maintained by the state, and in the current status quo.

\section{References}

Ally, S. (2009). From servants to workers: South African domestic workers and the democratic state. Ithaca, NY: Cornell University Press.

Amit, R., \& Kriger, N. (2014). Making migrants 'il-legible': The policies and practices of documentation in post-apartheid South Africa. Kronos, 40(1), 269-290.

Andall, J. (2017). Gender, migration and domestic service: The politics of black women in Italy. London: Routledge.

Anderson, B. (2010). Migration, immigration controls and the fashioning of precarious workers. Work, Employment \& society, 24(2), 300-317.

Arat-Koc, S. (1989). In the privacy of our own home: Foreign domestic workers as solution to the crisis in the domestic sphere in Canada. Studies in Political Economy, 28(1), 33-58.

Bakan, A. B., \& Stasiulis, D. K. (1995). Making the match: Domestic placement agencies and the racialization of women's household work. Signs: Journal of Women in Culture \& Society, 20(2), 303-335.

Bakan, A. B., \& Stasiulis, D. K. (Eds.). (1997). Not one of the family: Foreign domestic workers in Canada. Toronto, ON: University of Toronto Press.

Banki, S. (2013). Precarity of place: A complement to the growing precariat literature. Global Discourse, 3(3-4), 450-463.

Barchiesi, F. (2011). Precarious liberation: Workers, the state, and contested social citizenship in postapartheid South Africa. Albany, NY: SUNY Press.

Bolt, M. (2015). Zimbabwe's migrants and South Africa's border farms: The roots of impermanence. Cambridge: Cambridge University Press.

Budlender, D. (2010). Decent work for domestic workers [Study prepared for the SERVICES Sector Education and Training Authority]. Johannesburg, SA: Community Agency for Social Enquiry (CASE).

Burawoy, M. (1976). The functions and reproduction of migrant labour: Comparative material from Southern Africa and the United States. American Journal of Sociology, 81(5), 10501087.

Bystrom, K., \& Nuttall, S. (2013). Introduction: Private lives and public cultures in South Africa. Journal of Cultural Studies, 27(3), 307-332. 
Crenshaw, K. (1991). Mapping the margins: Intersectionality, identity politics, and violence against women of color. Stanford Law Review, 43(6), 1241-1299.

Duffy, M. (2011). Making care count: A century of gender, race, and paid care work. New Brunswick, NJ: Rutgers University Press.

Gaitskell, D., Kimble, J., Maconachie, M., \& Unterhalter, E. (1983). Class, race and gender: Domestic workers in South Africa. Review of African Political Economy, 10(27-28), 86108.

Glenn, E. N. (1992). From servitude to service work: Historical continuities in the racial division of paid reproductive labor. Signs: Journal of Women in Culture \& Society, 18(1), 1-43.

Goldring, L., \& Landolt, P. (2011). Caught in the work-citizenship matrix: The lasting effects of precarious legal status on work for Toronto immigrants. Globalizations, 8(3), 325-341. Griffin, L. (2011). Unravelling rights: 'Illegal' migrant domestic workers in South Africa. South African Review of Sociology, 42(2), 83-101.

Hopstock, N., \& de Jager, N. (2011). Locals only: Understanding xenophobia in South Africa. Strategic Review for Southern Africa, 33(1), p120-139.

International Labour Organization. (2015). Global estimates of migrant workers and migrant domestic workers: Results and methodology. Geneva, CH: International Labour Organization (ILO).

Jinnah, Z. (2017). Silence and invisibility: Exploring labour strategies of Zimbabwean farmworkers in Musina, South Africa. South African Review of Sociology, 48(3), 46-63.

Jørgensen, M. B., \& Schierup, C. U. (Eds.) (2016). Politics of precarity: Migrant conditions, struggles and experiences. Leiden, NL: Brill.

Kiwanuka, M., Jinnah, Z., \& Hartman-Pickerill, B. (2015). Getting the house in order: Foreign migrant workers in the domestic work sector in South Africa [MiWORC Report (10)]. Johannesburg, SA: MiWORC.

Kofman, E., \& Raghuram, P. (2012). Women, migration, and care: Explorations of diversity and dynamism in the Global South. Social Politics: International Studies in Gender, State \& Society, 9(3), 408-432.

Landau, L. B. (2010). Loving the alien? Citizenship, law, and the future in South Africa's demonic society. African Affairs, 109(435), 213-230.

Landau, L. B. (2018). Friendship fears and communities of convenience in Africa's urban estuaries: Connection as measure of urban condition. Urban Studies, 55(3), 505-521.

Millar, K. M. (2017). Toward a critical politics of precarity. Sociology Compass, 11(6), 1-11.

Moodie, T. D., \& Ndatshe, V. (1994). Going for gold: Men, mines, and migration. Berkeley, CA: University of California Press.

Munck, R. (2013). The precariat: A view from the south. Third World Quarterly, 34(5), 747-762.

National Institute of Mental Health. (1990). Clinical training in serious mental illness [DHHS Publication No. ADM 90-1679]. Washington, DC: U.S. Government Printing Office.

Neilson, B., \& Rossiter, N. (2008). Precarity as a political concept, or, Fordism as exception. Theory, Culture \& Society, 25(7-8), 51-72.

Nshimbi, C. C., \& Fioramonti, L. (2014). The will to integrate: South Africa's responses to regional migration from the SADC Region. African Development Review, 26(S1), 52-63.

Pang, I. (2018). The legal construction of precarity: Lessons from the construction sectors in Beijing and Delhi. Critical Sociology, 45(4-5), 549-564.

Paret, M. (2016). Politics of solidarity and agency in an age of precarity. Global Labour Journal, $7(2), 174-188$.

Parreñas, R. S. (2000). Migrant Filipina domestic workers and the international division of reproductive labour. Gender \& Society, 4(4), 560-580.

Hann, C., \& Parry, J. (Eds.). (2018). Industrial labor on the margins of capitalism: Precarity, class, and the neoliberal subject (Vol. 4). New York: Berghahn Books.

Peberdy, S., \& Dinat, N. (2005). Migration and domestic workers: Worlds of work, health and mobility in Johannesburg [Migration Policy Series \#40]. Southern African Migration Project, Queen's University, ON.

Piper, N. (2005). Gender and migration [Paper prepared for the Policy Analysis and Research Programme of the Global Commission on International Migration]. Geneva, $\mathrm{CH}$ : 
International Organization on Migration (IOM). Retrieved from

http://incedes.org.gt/Master/pipersesentacuatro.pdf

Polzer, T., \& Segatti, A. (2012). From the defense of migrants' rights to new political subjectivities: Gauteng migrants' organisations after the May 2008 crisis. In L. B. Landau (Ed.), Exorcising the demons within: Xenophobia, violence and statecraft in contemporary South Africa (pp. 200-225). Johannesburg, SA: Wits University Press.

Rogan, M., Roever, S., Chen, M., \& Carré, F. (2017). Informal employment in the Global South: Globalization, production relations, and 'precarity.' In A. Kalleberg \& S. Vallas (Eds.), Precarious work (pp. 307-333). Bingley, UK: Emerald Publishing.

Sassen, S. (2000). Women's burden: Counter-geographies of globalization and the feminization of survival. Journal of International Affairs, 53(2), 503-524.

Schierup, C. U., Munck, R., Likic-Brboric, B., \& Neergaard, A. (Eds.). (2015). Migration, precarity, and global governance: Challenges and opportunities for labour. Oxford: Oxford University Press.

Scully, B. (2012). The decline of work or the decline of workers? A review of Franco Barchiesi's precarious liberation. South African Review of Sociology, 43(1), 92-97.

Scully, B. (2016). Precarity north and south: A southern critique of Guy Standing. Global Labour Journal, 7(2), 160-173.

Standing, G. (2011), The precariat: The new dangerous class. London: Bloomsbury Academic Press.

Standing, G. (2012). The precariat: From denizens to citizens? Polity, 44(4), 588-608.

Standing, G. (2014). Understanding the precariat through labour and work. Development \& Change, 45(5), 963-980.

Stasiulis, D., \& Bakan, A. (2005). Negotiating citizenship: Migrant women in Canada and the global system. Toronto, ON: University of Toronto Press.

Statistics South Africa. (2012a). Quarterly labour force survey, third quarter. Pretoria, SA: Statistics South Africa.

Statistics South Africa. (2012b). Census 2011 metadata [Report no. 03-01-47 144]. Pretoria, SA: Statistics South Africa.

Statistics South Africa. (2013). General household survey of 2012. Pretoria, SA: Statistics South Africa.

Waite, L. (2009). A place and space for a critical geography of precarity? Geography Compass, 3(1), 412-433.

Wolpe, H. (1972). Capitalism and cheap labour-power in South Africa: From segregation to apartheid. Economy \& Society, 1(4), 425-456.

Yeates, N. (2009). Globalizing care economies and migrant workers: Explorations in global care chains. New York: Palgrave Macmillan. 